Economics Development Analysis Journal 6(4)(2017)

\title{
Kausalitas Ekspor Indonesia ke Tiongkok dengan Inflasi Indonesia, Suku Bunga Dasar Tiongkok, dan Nilai Tukar Indonesia
}

\author{
Teddy Aldwin Leonard ${ }^{\bowtie}$
}

Jurusan Ekonomi Pembangunan, Fakultas Ekonomi, Universitas Negeri Semarang

\begin{tabular}{|c|c|}
\hline Info Artikel & Abstrak \\
\hline $\begin{array}{l}\text { Sejarah Artikel: } \\
\text { Diterima Juli } 2017 \\
\text { Disetujui September } 2017 \\
\text { Dipublikasikan } \\
\text { November } 2017\end{array}$ & $\begin{array}{l}\text { Tujuan penelitian ini adalah mengetahui hubungan kausalitas antara total nilai ekspor Indonesia ke } \\
\text { Tiongkok dengan tingkat suku bunga Tiongkok, tingkat inflasi Indonesia, dan nilai tukar Rupiah } \\
\text { Indonesia terhadap Yuan China. Penelitian ini menggunakan uji kausalitas granger dengan variabel } \\
\text { total nilai ekspor Indonesia ke Tiongkok, tingkat inflasi Indonesia, tingkat suku bunga dasar } \\
\text { Tiongkok, dan nilai tukar Rupiah Indonesia terhadap Yuan China untuk melihat hubungan } \\
\text { kausalitas antar variabel. Hasil uji kausalitas granger menunjukkan hasil bahwa total nilai ekspor }\end{array}$ \\
\hline $\begin{array}{l}\text { Keywords: } \\
\text { interest rate, inflation, } \\
\text { export, exchange rate, } \\
\text { granger causality }\end{array}$ & $\begin{array}{l}\text { Indonesia ke Tiongkok memiliki hubungan satu arah dengan variabel tingkat suku bunga Tiongkok } \\
\text { dan variabel nilai tukar Rupiah Indonesia terhadap Yuan China, namun tidak terdapat hubungan } \\
\text { kausalitas dengan variabel tingkat inflasi Indonesia. Hubungan satu arah antara total nilai ekspor } \\
\text { Indonesia ke Tiongkok dengan tingkat suku bunga Tiongkok adalah total nilai ekspor Indonesia ke } \\
\text { Tiongkok menyebabkan perubahan tingkat suku bunga Tiongkok, sedangkan hubungan satu arah } \\
\text { antara total nilai ekspor Indonesia ke Tiongkok dengan nilai tukar Rupiah Indonesia terhadap Yuan } \\
\text { China adalah nilai tukar Rupiah Indonesia terhadap Yuan China menyebabkan perubahan total } \\
\text { nilai ekspor Indonesia ke Tiongkok. }\end{array}$ \\
\hline
\end{tabular}

\begin{abstract}
The purpose of this study is to know the causality relationship between the total value of Indonesia's exports to Tiongkok with Tiongkok's interest rate, the inflation rate of Indonesia, and the exchange rate of Indonesian Rupiah against the Yuan China. This study uses granger causality test with total variable of Indonesian export value to Tiongkok, Indonesia inflation rate, interest rate of Tiongkok, and Indonesian Rupiah exchange rate to Yuan China to see the relation of causality among variables. Granger causality test results show that the total value of Indonesia's export to Tiongkok has unidirectional relationship with variable of Tiongkok interest rate and variable of Indonesian Rupiah exchange rate to Yuan China, but there is no causality relationship with Indonesian inflation rate variable. The unidirectional relationship between the total value of Indonesia's exports to Tiongkok and the Tiongkok interest rate is the total value of Indonesia's exports to Tiongkok causing a change in the Tiongkok interest rate, while the unidirectional relationship between the total value of Indonesia's exports to Tiongkok and the Indonesian rupiah against the Yuan China is the value The Indonesian rupiah exchange rate against the Yuan China led to a change in the total value of Indonesia's exports to Tiongkok.
\end{abstract}

(C) 2017 Universitas Negeri Semarang

\footnotetext{
${ }^{\bowtie}$ Alamat korespondensi:

Gedung L2 Lantai 2 FE Unnes

Kampus Sekaran, Gunungpati, Semarang, 50229

E-mail: edaj@mail.unnes.ac.id
} ISSN 2252-6963 


\section{PENDAHULUAN}

Mengejar pertumbuhan ekonomi yang tinggi dan berkelanjutan adalah salah satu perhatian utama bagi negara, terutama negara berkembang untuk mencapai ekonomi mereka pengembangan (Karabou, 2017). Pada kondisi pertumbuhan kondisi perekonomian global memberi tekanan pada ekspor Indonesia. Umumnya liberalisasi perdagangan yang berkelanjutan harus mengarah pada perluasan perdagangan luar negeri negara baik dalam impor dan ekspor dan dalam tingkat absolut maupun proporsi produk negara (Sofjan, 2017). Ada berbagai macam tekanan seperti krisis dibeberapa negara maju di Eropa tahun 2011, masalah geopolitik di timur tengah, perlambatan ekonomi dunia. Salah satu negara yang sedang mengalami perlambatan ekonomi dan memberi dampak pada penurunan ekspor Indonesia adalah Tiongkok. Kondisi perekonomian Tiongkok mengalami perlambatan salah satunya disebabkan oleh adanya rebalancing economy Tiongkok. Dampak perlambatan ekonomi Tiongkok tercermin dari trend menurun dan berfluktuasi dari ekspor Indonesia ke Tiongkok. Ekspor Indonesia ke Tiongkok cukup penting karena ekspor Indonesia ke Tiongkok termasuk nilai ekspor tiga terbesar Indonesia ke negara tujuan ekspor.

Ada beberapa faktor yang mempengaruhi ekspor Indonesia ke Tiongkok. Kebijakan perekonomian Tiongkok yang dapat mempengaruhi ekspor Indonesia ke Tiongkok adalah kebijakan penurunan suku bunga dasar Tiongkok yang merupakan respon dari perlambatan Tiongkok. Tingkat bunga dunia menentukan tingkat bunga dalam perekonomian terbuka kecil. (Mankiw, 2006) dan meningkatnya tingkat suku bunga mengurangi arus modal keluar neto yang berarti berkurangnya penawaran dolar di pasar valuta asing sehingga menyebabkan kurs riil mengalami apresiasi dan ekspor neto turun. (Mankiw, 2006), artinya tingkat suku bunga Tiongkok dapat mempengaruhi tingkat suku bunga Indonesia dan secara tidak langsung dapat mempengaruhi ekspor Indonesia ke Tiongkok.

Selain itu, faktor yang dapat mempengaruhi ekspor Indonesia ke Tiongkok adalah inflasi Indonesia. Penawaran barang dan jasa sangat bergantung pada faktor produksi seperti yang diperlihatkan dari fungsi produksi $Y=F(K, L)$, dimana $\mathrm{Y}$ adalah output, $\mathrm{K}$ adalah jumlah modal, dan L adalah jumlah tenaga kerja. (Mankiw, 2006). Hubungan negatif antara jumlah faktor produksi dengan harga faktor produksi menunjukkan bahwa semakin tingginya harga akan menurunkan jumlah faktor produksi yang selanjutnya akan mengurangi jumlah output termasuk output dari barang-barang yang akan dijual keluar negeri (ekspor). Faktor lain yang juga dapat memberi pengaruh pada harga barang ekspor dan jumlah penawaran ekspor adalah nilai tukar Rupiah Indonesia terhadap Yuan China. Semakin rendah kurs, semakin murah harga barang domestik relatif terhadap barang-barang luar negeri, dan semakin besar ekspor neto kita. (Mankiw, 2006). Nilai tukar Rupiah Indonesia terhadap Yuan Tiongkok yang terdepresi akan menyebabkan harga barang ekspor Indonesia relatif semakin murah dibanding barang domestik Tiongkok. Nilai tukar menjadi konsentrasi karena menurut Abebrese (2017) pergerakan nilai tukar luar biasa besar dan telah memicu perdebatan tentang kemungkinan efek pada perdagangan dan pertumbuhan ekonomi komoditas negara pengekspor.

Melihat permasalahan tersebut maka peneliti ingin mengetahui hubungan kausalitas antara ekspor Indonesia ke Tiongkok dengan beberapa faktor yang mempengaruhi yang telah disebutkan diatas, sehingga dapat tercapai tujuan penelitian ini yaitu mengetahui hubungan kausalitas antara total nilai ekspor Indonesia ke Tiongkok dengan tingkat suku bunga Tiongkok, tingkat inflasi Indonesia, dan nilai tukar Rupiah Indonesia terhadap Yuan China.

\section{METODE PENELITIAN}

Jenis penelitian ini termasuk kedalam penelitian kuantitatif. Penelitian ini menggunakan data sekunder dengan teknik pengumpulan data arsip. Data sekunder didapatkan dari beberapa sumber seperti website lembaga pemerintah atau lembaga independent seperti Badan Pusat Statistik (BPS), Kementrian Perdagangan (Kemendag), Bank Indonesia(Bank Indonesia) dan beberapa website lain seperti www.ieconomics.com ataupun www.tradingeconomic.com sebagai website yang 
menyajikan data salah satunya dari People Bank of China.

Variabel yang digunakan dalam penelitian ini adalah variabel tingkat inflasi Indonesia, variabel tingkat suku bunga Tiongkok, kurs tengah nilai tukar rupiah Indonesia terhadap yuan Tiongkok dan variabel total nilai ekspor Indonesia ke Tiongkok.

Penelitian ini menggunakan alat analisis granger causality. Kausalitas adalah hubungan dua arah. (Widarjono, 2009). Uji granger causality digunakan untuk mengetahui hubungan kausalitas antar variabel. Model persamaan kausalitas granger dapat ditulis sebagai berikut (Widarjono, 2009) :

$Y_{t}=\sum_{i=1}^{n} \alpha_{i} Y_{t-1}+\sum_{i=1}^{n} \beta_{i} X_{t-1}+e_{1 t}$

$X_{t}=\sum_{i=1}^{m} \gamma_{i} X_{t-1}+\sum_{i=1}^{m} \lambda_{i} Y_{t-1}+e_{2 t}$

Selanjutnya untuk menyelesaikan persamaan diatas maka ada dua persamaan untuk menjelaskan variabel $\mathrm{X}$ mempengaruhi $\mathrm{Y}$ dan sebaliknya dua persamaan juga untuk menjelaskan variabel $Y$ mempengaruhi $X$. Dua Persamaan untuk menjelaskan variabel $\mathrm{Y}$ mempengaruihi $\mathrm{X}$ adalah sebagai berikut (Widarjono, 2009): Persamaan unrestricted

$Y_{t}=\sum_{i=1}^{n} \alpha_{i} Y_{t-1}+\sum_{i=1}^{n} \beta_{i} X_{t-1}+e_{1 t}$

Persamaan restricted

$Y_{t}=\sum_{i=1}^{m} \gamma_{i} Y_{t-1}+e_{2 t}$

Dua Persamaan untuk menjelaskan variabel $\mathrm{X}$ mempengaruhi $\mathrm{Y}$ adalah sebagai berikut (Widarjono, 2009):

Persamaan unrestricted
$X_{t}=\sum_{i=1}^{n} \alpha_{i} X_{t-1}+\sum_{i=1}^{n} \lambda_{i} Y_{t-1}+e_{1 t}$

Persamaan restricted

$X_{t}=\sum_{i=1}^{m} \gamma_{i} X_{t-1}+e_{2 t}$

Langkah berikutnya untuk mengetahui hubungan kausal antar variabel $\mathrm{X}$ dan $\mathrm{Y}$ digunakan uji $\mathrm{F}$. Nilai $\mathrm{F}$ hitung diperoleh dari formula sebagai berikut (Widarjono, 2009):

$F=(n-k) \frac{\left(R S S_{R}-R S S_{U R}\right)}{m\left(R S S_{U R}\right)}$

Keterangan :

$\mathrm{RSS}_{\mathrm{R}}$ adalah residual sum of squares persamaan restricted.

$\mathrm{RSS}_{\mathrm{UR}}$ adalah residual sum of squares persamaan unrestricted.

$\mathrm{n}$ adalah jumlah observasi.

$m$ adalah jumlah lag.

$\mathrm{k}$ adalah parameter yang diestimasi di dalam persamaan unrestricted.

Hasil uji $F$ jika nilai $F$ hitung lebih besar dari $\mathrm{F}$ table maka variabel $\mathrm{Y}$ mempengaruhi variabel $\mathrm{X}$ atau sebaliknya. Selain itu dapat pula menggunakan nilai probability, jika nilai probability lebih kecil dari nilai $\alpha$ (alpha) maka variabel $\mathrm{Y}$ mempengaruhi variabel $\mathrm{X}$ atau sebaliknya.

\section{HASIL DAN PEMBAHASAN}

\section{Hasil Uji Kausalitas Granger}

Hasil Uji kausalitas granger dengan lag 1 (penentuan lag berdasarkan SIC)menggunakan aplikasi Eviews 7 menunjukkan hasil sebagai berikut :

Tabel 1. Hasil Uji Kausalitas Granger

\begin{tabular}{lll}
\hline $\begin{array}{c}\text { Nilai } \\
\text { Probability }\end{array}$ & \multicolumn{1}{c}{ Keputusan } & Hubungan \\
\hline 0.7219 & INF tidak menyebabkan perubahan EKS & Tidak Ada \\
0.3787 & EKS tidak menyebabkan perubahan INF & \\
0.1157 & INT tidak menyebabkan perubahan EKS & Satu Arah \\
0.0246 & EKS menyebabkan perubahan INT & \\
0.0099 & KURS menyebabkan perubahan EKS & Satu Arah \\
0.5653 & EKS tidak menyebabkan perubahan KURS & \\
\hline
\end{tabular}




\begin{tabular}{lll}
\hline 0.1249 & INT tidak menyebabkan perubahan INF & Tidak Ada \\
0.5581 & INF tidak menyebabkan perubahan INT & \\
0.2270 & KURS tidak menyebabkan perubahan INF & Satu Arah \\
0.0012 & INF menyebabkan perubahan KURS & \\
0.0260 & KURS menyebabkan perubahan INT & Satu Arah \\
0.0536 & INT tidak menyebabkan perubahan EKS &
\end{tabular}

Hasil uji hubungan kausalitas antara variabel INF (tingkat inflasi Indonesia) dan EKS (total nilai ekspor Indonesia ke Tiongkok) tidak menunjukkan adanya hubungan. Hal yang sama juga terjadi antara variabel INF dengan variabel INT (tingkat suku bunga dasar Tiongkok). Hasil uji kausalitas granger juga m,enunjukkan bahwa hubungan kausalitas dua arah tidak terjadi antar variabel yang diuji, namun terjadi empat hubungan satu arah yaitu variabel EKS menyebabkan perubahan variabel INT, variabel KURS (Nilai Tukar Rupiah Indonesia terhadap Yuan China) menyebabkan perubahan EKS, Variabel INF menyebabkan perubahan KURS dan variabel KURS menyebabkan perubahan variabel INT.

\section{Hubungan Kausalitas antara Tingkat Inflasi Indonesia dengan Total Nilai Ekspor Indonesia ke Tiongkok}

Hasil olah data menggunakan uji kausalitas granger menunjukkan total nilai ekspor Indonesia ke Tiongkok tidak terdapat hubungan kausalitas dengan tingkat inflasi Indonesia. Jika dilihat dari pola data, trend data tingkat inflasi Indonesia berfluktuasi seperti total nilai ekspor Indonesia ke Tiongkok, namun yang jadi perbedaan disini adalah fluktuasi yang terjadi pada total nilai ekspor Indonesia ke Tiongkok lebih sering terjadi dibanding tingkat inflasi Indonesia dan trend penurunan lebih terlihat pada total nilai ekspor Indonesia ke Tiongkok dibanding dengan tingkat inflasi Indonesia, hal tersebut menjadi alasan tidak adanya hubungan kausalitas antara tingkat inflasi dengan total nilai ekspor Indonesia ke Tiongkok. Hal tersebut tidak sesuai dengan jurnal berjudul "Determinants of Export Performance in Tanzania" (EPAPHRA, 2016) yang menemukan bahwa inflasi memiliki pengaruh negatif terhadap ekspor. Secara teori inflasi akan menaikkan biaya faktor produksi dan dapat menyebabkan perubahan jumlah barang yang akan diproduksi termasuk barang ekspor.

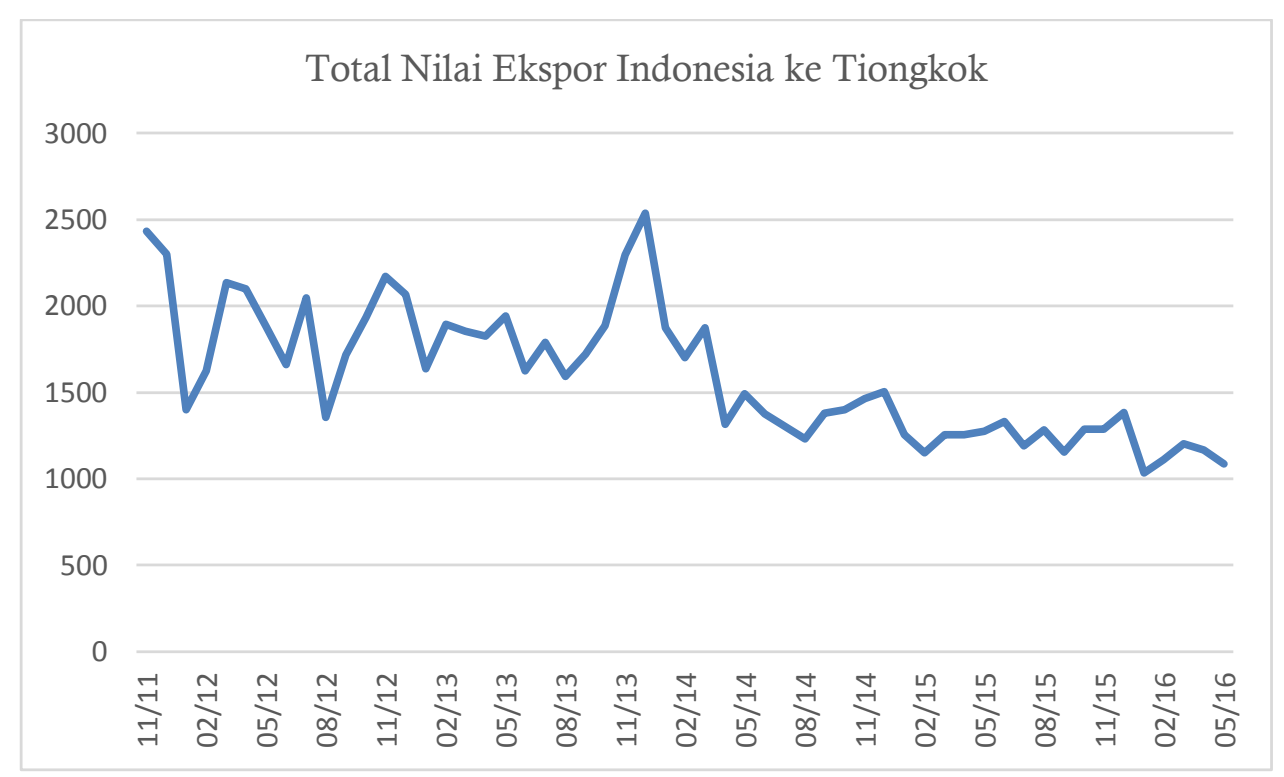

Sumber : Badan Pusat Statistik

Gambar 1. Total Nilai Ekspor Indonesia ke Tiongkok Januari 2011 - Mei 2016 


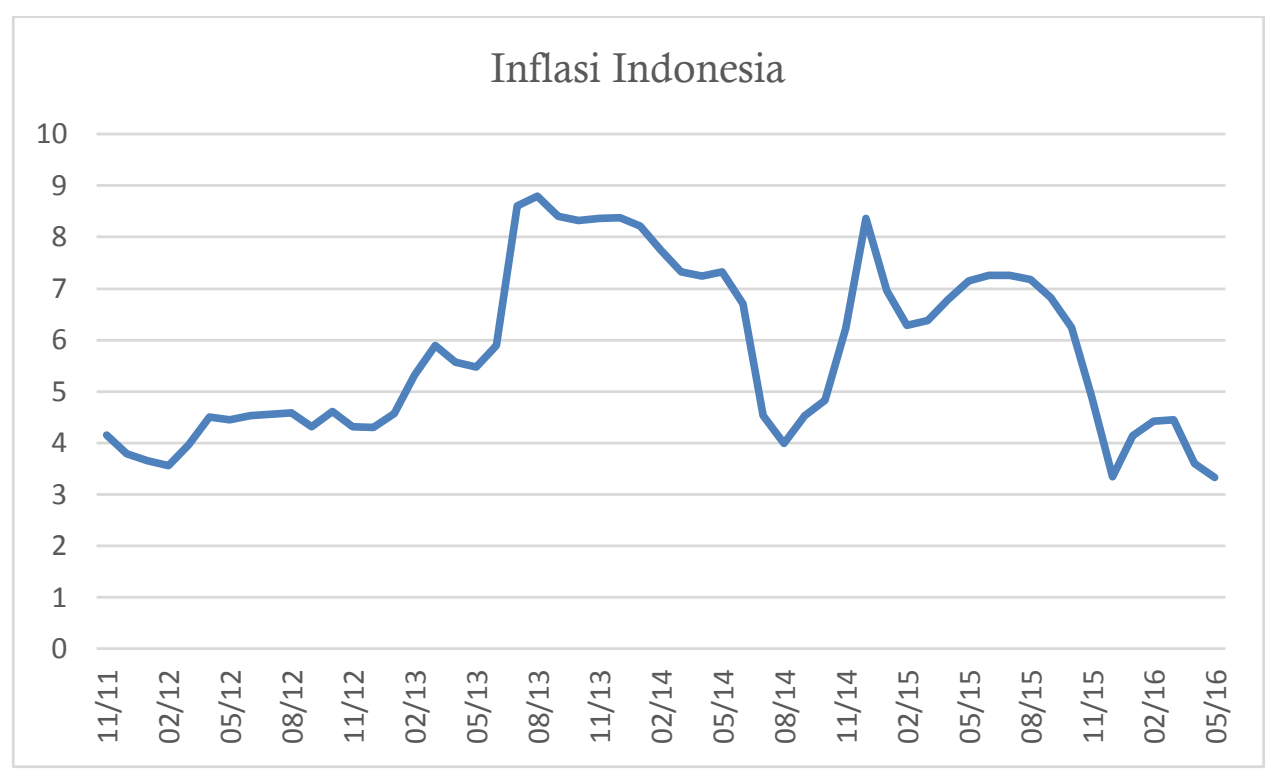

Sumber : Bank Indonesia

Gambar 2. Tingkat Inflasi Indonesia Januari 2011-Mei 2016

Jika dilihat dari kondisi empirisnya tingkat inflasi Indonesia pada tahun 2013 hingga masuk tahun 2014 menurun lebih dikarenakan oleh pengaruh perlambatan ekonomi dunia yang terjadi pada saat itu yang mengakibatkan tekanan imported inflation menurun dan bukan karena ekspor Indonesia ke Tiongkok. Sedangkan perubahan total nilai ekspor Indonesia ke Tiongkok lebih dsebabkan oleh turunnya volume ekspor seperti komoditi batubara dan karet karena kebijakan pembatasan batu bara atau permintaan yang berkurang dari industri ban Tiongkok oleh karena itu tidak terdapat hubungan kausalitas antara tingkat inflasi dengan total nilai ekspor Indonesia ke Tiongkok.

\section{Hubungan Kausalitas antara Total Nilai Ekspor Indonesia ke Tiongkok dengan Tingkat Suku Bunga Tiongkok}

Hasil olah data menggunakan uji kausalitas granger menunjukkan nilai ekspor Indonesia ke Tiongkok menyebabkan perubahan tingkat suku bunga Tiongkok. Hal tersebut tidak sesuai teori karena, meningkatnya tingkat suku bunga mengurangi arus modal keluar neto yang berarti berkurangnya penawaran dolar di pasar valuta asing sehingga menyebabkan kurs riil mengalami apresiasi dan ekspor neto turun. (Mankiw, 2006).
Namun kegiatan ekspor yang meningkat dan mampu memberi surplus perdagangan dapat meningkatkan kurs nominal sebuah negara artinya harga barang di negara tersebut relatif mahal dibanding barang luar negeri (Tiongkok). Jika inflasi Tiongkok turun dan tidak sesuai target maka untuk meningkatkannya dapat menggunakan instrumen suku bunga dengan cara menurunkannya. Secara kondisi empirisnya adalah kondisi ekspor Indonesia ke Tiongkok sedang mengalami trend menurun yang merupakan sebagai salah satu langkah Tiongkok dalam menanggapi perlambatan ekonomi Tiongkok yang sedang menurun sehingga sangat wajar kenapa tingkat suku bunga Tiongkok tidak menyebabkan perubahan total nilai ekspor Indonesia ke Tiongkok.

Pola data tingkat suku bunga tingkat suku bunga dasar Tiongkok menunjukkan trend menurun hal ini sama terjadi dengan total nilai ekspor Indonesia ke Tiongkok, sedangkan pola fluktuasi data yang terjadi pada total nilai ekspor Indonesia ke Tiongkok (Gambar 1) tidak terjadi pada tingkat suku bunga Tiongkok yang cenderung menurun sehingga yang terjadi adalah hubungan satu arah dari tingkat suku bunga Tiongkok dengan total nilai ekspor Indonesia ke Tiongkok. 
Hubungan Kausalitas antara Nilai Tukar Rupiah Indonesia terhadap Yuan China dengan Total Nilai Ekspor Indonesia ke Tiongkok

Hasil olah data menggunakan uji kausalitas granger menunjukkan total nilai ekspor Indonesia ke Tiongkok terdapat hubungan kausalitas dengan nilai tukar Rupiah Indonesia terhadap Yuan China. Hubungan yang terjadi adalah hubungan satu arah yaitu hubungan nilai tukar Rupiah Indonesia terhadap Yuan China menyebabkan perubahan Total Nilai Ekspor Indonesia ke Tiongkok. Hal tersebut sesuai dengan beberapa jurnal yaitu jurnal berjudul "Determinants of Export Performance in Tanzania" (EPAPHRA, 2016) yang menunjukkan hasil bahwa nilai tukar real menyebabkan perubahan ekspor, jurnal berjudul "The Influence of Exchange Rate on Indonesia's Exports"(Ginting, 2013) yang menemukan bahwa nilai tukar dalam jangka panjang dan jangka pendek memiliki pengaruh negatif terhadap ekspor, jurmal berjudul "Cointegration and Causality Test Among Export, Import, and Foreign Exchange"(Subiyakto, Algifari, 2016) menemukan bahwa foreign exchange berpengaruh terhadap ekspor, dan berbeda dengan jurnal berjudul "Pengaruh Jumlah Uang Beredar (Jub), Suku Bunga Sertifikat Bank Indonesia (Sbi), Impor, Ekspor Terhadap Kurs Rupiah/ Dollar Amerika Serikat Periode Januari 2006 sampai Maret 2010" (U1fa, 2012) yang menemukan bahwa ekspor mempunyai pengaruh negatif terhadap kurs.

Sesuai dengan pernyataan (Mankiw, 2006) hubungan antara kurs riil dan ekspor neto, semakin rendah kurs, semakin murah harga barang domestik relatif terhadap barang-barang luar negeri, dan semakin besar ekspor neto kita. Selanjutnya (Mankiw, 2006) juga memberi pernyataan bahwa berdasarkan nilai kurs riil, jika tingkat harga domestik meningkat, maka kurs nominal akan turun. Artinya jika kurs nomilnal Indonesia turun (terdepresiasi) maka semakin semakin banyak rupiah yang harus ditukarkan untuk mendapatkan yuan China sehingga barang ekspor Indonesia akan semakin terlihat murah harganya ketika dijual ke negara Tiongkok karena untuk mendapatkan barang ekspor dari Indonesia, Tiongkok hanya perlu menukarkan sedikit yuan China untuk mendapatkan rupiah Indonesia ketika rupiah Indonesia terdepresiasi.

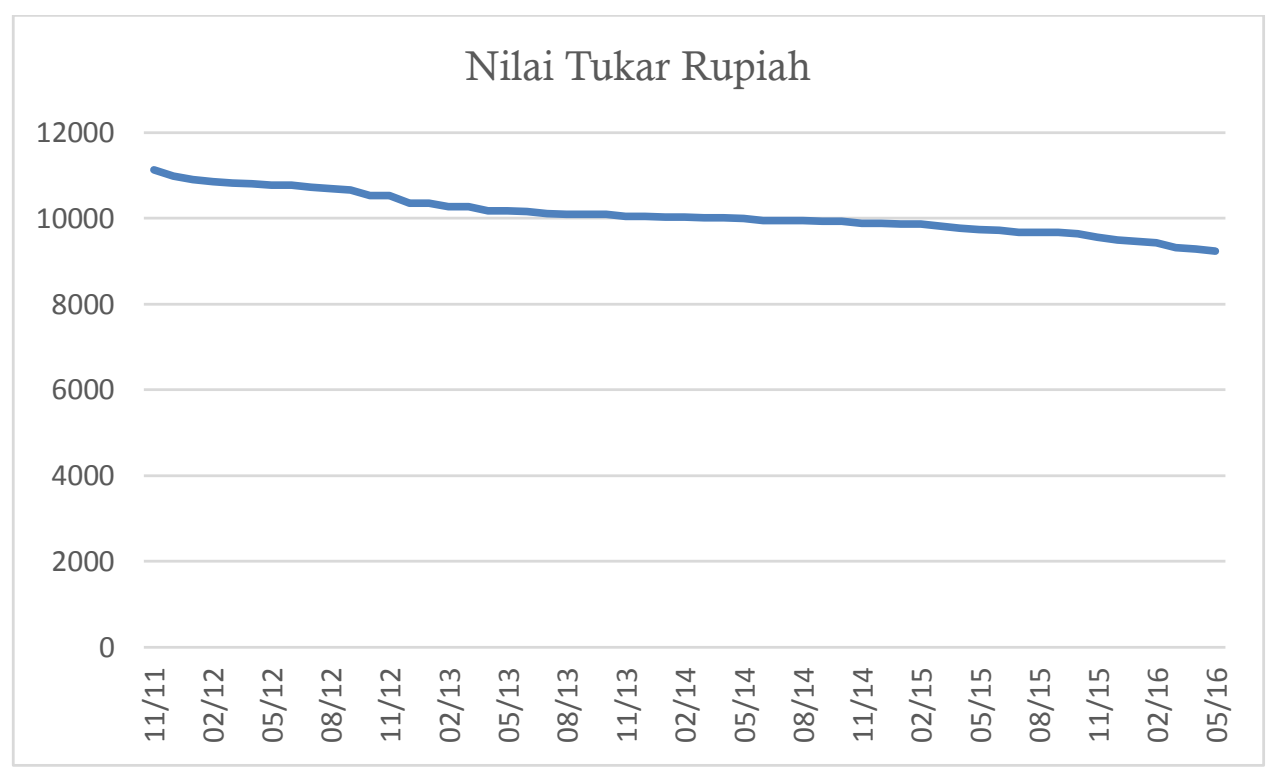

Sumber : Bank Indonesia

Gambar 3. Nilai Tukar Rupiah Indonesia terhadap Yuan China

Melihat pola data menunjukkan total nilai ekspor Indonesia ke Tiongkok memiliki trend yang menurun dengan fluktuasi data (Gambar 1) sedangkan pola data nilai tukar Rupiah Indonesia terhadap Yuan China menunjukkan trend menurun dengan fluktuasi yang sangat sedikit sekali (Gambar 
3). Hal tersebut menjadi alasan mengapa hubungan yang terjadi antara nilai tukar Rupiah Indonesia terhadap Yuan China dengan total nilai ekspor Indonesia ke Tiongkok memiliki arah hubungan dari nilai tukar Rupiah Indonesia terhadap Yuan Tiongkok ke total nilai ekspor Indonesia ke Tiongkok, hal ini dikarenakan pola trend menurun yang terjadi pada nilai tukar Rupiah Indonesia terhadap Yuan Tiongkok diikuti oleh trend menurun total nilai ekspor Indonesia ke Tiongkok bukan sebaliknya yaitu fluktuasi pada total nilai ekspor Indonesia ke Tiongkok diikuti oleh nilai tukar Rupiah Indonesia terhadap Yuan China.

\section{SIMPULAN}

Kesimpulan yang dapat diambil dari pembahasan diatas adalah tidak terdapat hubungan kausalitas antara total nilai ekspor Indonesia ke Tiongkok dengan inflasi Indonesia. Jika dilihat dari pola data, trend data tingkat inflasi Indonesia berfluktuasi seperti total nilai ekspor Indonesia ke Tiongkok, namun yang jadi perbedaan disini adalah fluktuasi yang terjadi pada total nilai ekspor Indonesia ke Tiongkok lebih sering terjadi dibanding tingkat inflasi Indonesia dan trend penurunan lebih terlihat pada total nilai ekspor Indonesia ke Tiongkok dibanding dengan tingkat inflasi Indonesia, hal tersebut menjadi alasan tidak adanya hubungan kausalitas antara tingkat inflasi dengan total nilai ekspor Indonesia ke Tiongkok.

Terdapat hubungan satu arah antara total nilai ekspor Indonesia ke Tiongkok dengan tingkat suku bunga Tiongkok. Pola data tingkat suku bunga tingkat suku bunga dasar Tiongkok menunjukkan trend menurun dan juga terjadi pada data total nilai ekspor Indonesia ke Tiongkok, sedangkan pola fluktuasi data yang terjadi pada total nilai ekspor Indonesia ke Tiongkok tidak terjadi pada tingkat suku bunga Tiongkok yang cenderung menurun sehingga dapat disimpulkan bahwa turunnya tingkat suku bunga Tiongkok akan diikuti oleh turunnya total nilai ekspor Indonesia ke Tiongkok.

Terdapat hubungan satu arah antara total nilai ekspor Indonesia ke Tiongkok dengan nilai tukar Rupiah Indonesia terhadap Yuan China. Hubungan yang terjadi adalah hubungan nilai tukar rupiah Indonesia terhadap Yuan China menyebabkan perubahan total nilai ekspor Indonesia ke Tiongkok. Pola data menunjukkan total nilai ekspor Indonesia ke Tiongkok memiliki trend yang menurun dengan fluktuasi data sedangkan pola data nilai tukar Rupiah Indonesia terhadap Yuan China menunjukkan trend menurun dengan fluktuasi yang sangat sedikit. Hal tersebut menjadi alasan mengapa hubungan yang terjadi antara nilai tukar Rupiah Indonesia terhadap Yuan China dengan total nilai ekspor Indonesia ke Tiongkok memiliki arah hubungan dari nilai tukar Rupiah Indonesia terhadap Yuan Tiongkok ke total nilai ekspor Indonesia ke Tiongkok, hal ini dikarenakan pola trend menurun yang terjadi pada nilai tukar Rupiah Indonesia terhadap Yuan Tiongkok diikuti oleh trend menurun total nilai ekspor Indonesia ke Tiongkok bukan sebaliknya yaitu fluktuasi pada total nilai ekspor Indonesia ke Tiongkok diikuti oleh nilai tukar Rupiah Indonesia terhadap Yuan China. Jadi jika dilihat dari data maka turunnya nilai tukar Rupiah Indonesia terhadap Yuan China akan diikuti oleh turunnya total nilai ekspor Indonesia ke Tiongkok.

\section{DAFTAR PUSTAKA}

Abebrese, J. O., Pickson, R. P., Abebrese, G. O. 2017. Commodity prices, exchange rate and economic growth in West Africa: Case study of Cote d'Ivoire and Ghana. Jounal of Development and Agricultural Economics, 9(9), 269-277.

Badan Pusat Statistik. Berbagai Tahun. Analisa Komoditi Ekspor 2008 - 2014. Jakarta: Badan Pusat Statistik

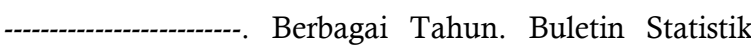
Perdagangan Luar Negeri Ekspor Menurut Harmonized System (berbagai edisi). Jakarta: Badan Pusat Statistik.

. Berbagai Tahun. Buletin Statistik Perdagangan Luar Negeri Ekspor Menurut Kelompok Komoditi Negara (berbagai edisi). Jakarta: Badan Pusat Statistik.

Bank Indonesia. 2017. Kurs Transaksi BI - Bank Sentral Republik Indonesia. http://www.bi.go.id/id/moneter/inflasi/data /Default.aspx.

Berbagai Tahun. Data Inflasi - Bank Sentral Republik Indonesia. 
Teddy Aldwin Leonard / Economics Development Analysis Journal 6 (4) (2017)

http://www.bi.go.id/id/moneter/informasikurs/transaksi-bi/Default.aspx.

$$
\text { Berbagai Tahun. Laporan }
$$

Perekonomian Indonesia. Jakarta: Bank Indonesia

Bank Indonesia. Berbagai Tahun. Perkembangan Ekonomi Keuangan dan Kerjasama Internasional (berbagai edisi). Jakarta: Bank Indonesia.

EPAPHRA, Manamba. 2016. "Determinants of Export Performance in Tanzania" Dalam Journal of Economics Library. Volume 3 No.3. Hal 470-487.

Ginting, Ari Mulianta. 2013. "The Influence of Exchange Rate on Indonesia's Exports" Dalam Buletin Ilmiah Litbang Perdagangan. Volume 7 No.1. Hal 1-18.

Ieconomics. 2015. China Interest Rate. https://ieconomics.com/china-interest-rate.

Kemendag. 2015. Neraca Perdagangan Indonesia Total. http://www.kemendag.go.id/id/economicprofile/indonesia-export-import/indonesiatrade-balance.
Sofjan, M. 2017. The Effect of Liberalization on Exportimport in Indonesia. International Journal of Economics and Financial Issues, 7(2), 672-676.

Tradingeconomics. 2017. China Interest Rate. https://tradingeconomics.com/china/interestrate.

Ulfa, Siti Aminah. 2012. "Pengaruh Jumlah Uang Beredar (Jub), Suku Bunga Sertifikat Bank Indonesia (Sbi), Impor, Ekspor Terhadap Kurs Rupiah/ Dollar Amerika Serikat Periode Januari 2006 sampai Maret 2010. Dalam Economics Development Analysis Journal Volume $1 \mathrm{Hal} 42-48$

Widarjono, Agus. 2009. Ekonometrika Pengantar dan Aplikasinya. Yogyakarta: Ekonisia.

Karabou, E. F. 2017. Exports and economic growth in Togo. Journal of Economics and International Finance, 9(3), 19-29.

Mankiw, Gregory N. 2006. Makroekonomi Edisi Keenam. Terjemahan Fitria Liza dan Imam Nurmawan. Jakarta: Erlangga.

Subiyakto, Haryono dan Algifari. 2016. "Cointegration and Causality Test Among Export, Import, and Foreign Exchange" Dalam Journal of Economics and Policy Volume 9. Hal 82-95. 